\title{
WHEN HE TOOK ME OUT WITH HIS PEOPLE
}

When he took me out with his people, I could see he was ashamed of me. The next youngest guy there was twenty years older than I.

It is traditional to revile incompetence, and to stop one's ears to excuses. We are all of us crying infants, if only we knew it.

To forgive Thwarting Reality is not easy. It's like trying to Pry your father's hand off a thing, working on one finger at a time.

A barefoot Virgin Mary will have no trouble counting to twenty. But unless he takes his pants off, a boy'll never make it to twenty-one.

If you can't hand him a book of aphorisms and trust him to pick out the best, What good can he possibly be to you when you're roommates-for-life-?

I'll take as my model a microbe that only lives half a second. That's just Long enough to take one bite out of the universe and die...

For today's one bite, MADRID offers this Hindu truth. He says Even this jagged hunk of quartz will one day flex its back and run up a tree. 